\title{
Association of HLA-DM polymorphism with the production of antiphospholipid antibodies
}

\author{
M L Sanchez, K Katsumata, T Atsumi, F I Romero, M L Bertolaccini, A Funke, O Amengual, \\ E Kondeatis, R W Vaughan, A Cox, G R V Hughes, M A Khamashta
}

Ann Rheum Dis 2004;63:1645-1648. doi: 10.1136/ard.2003.015552

See end of article for authors' affiliations

.....................

Correspondence to: M A Khamashta, Lupus Research Unit, The Rayne Institute, St Thomas' Hospital, London, SEl 7EH, UK; munther. khamashta@kcl.ac.uk

Accepted 5 March 2004
Objective: To investigate whether variation in the HLA-DM gene is important in producing a group of pathogenic autoantibodies - antiphospholipid antibodies (aPL) - on the basis that HLA class II restricted antigen presentation is involved in the production of aPL.

Methods: HLA-DMA and DMB polymorphisms were genotyped by polymerase chain reaction combined with restriction enzyme digestion in 51 white patients with primary antiphospholipid syndrome (APS), 82 with systemic lupus erythematosus (SLE) (42 with APS and 40 without APS), and 109 healthy white controls. The association with the aPL profile was examined.

Results: The distribution of DMA alleles in APS patients and in patients with APS associated with SLE was significantly different from that in controls by $4 \times 2 \chi^{2}$ test with 3 degrees of freedom $(p=0.035$ and 0.011 , respectively), but it was not different between SLE patients without APS and controls. The allelic distribution of DMA was also different between patients with $\lg G$ class anticardiolipin antibody or those with lupus anticoagulant (LA) and controls ( $p=0.012$ and 0.007 , respectively) and between patients with and without LA among SLE patients $(p=0.035)$. All these differences included the increase in DMA*0102 in the former groups.

Conclusions: The results suggest that HLA-DMA*0102 or its linked gene(s) form one of the genetic risks for the production of aPL. l is now becoming evident that certain groups of antiphospholipid antibodies (aPL) play causative roles in thrombosis. However, the mechanisms of production of aPL are still unclear. The analyses of $\mathrm{V}$ genes of human monoclonal aPL suggest the involvement of antigen driven positive selection at a certain stage in generating pathogenic aPL. ${ }^{12}$ Associations between the presence of aPL or antiphospholipid syndrome (APS) and HLA class II genes have been reported, supporting this antigen driven mechanism..$^{3-10}$

HLA-DM are recently identified molecules that are encoded by HLA-DMA and DMB genes located between HLA-DQ and DP subregions of the human major histocompatibility complex. ${ }^{11}$ They accumulate in acidic endosomal/lysosomal compartments associated with classical class II molecules, protecting the empty $\alpha \beta$ dimers of those molecules from functional inactivation by low $\mathrm{pH}$. They also catalyse peptide loading by releasing class II associated invariant chain peptide or low stability ligands toward high stability $\alpha \beta$ :peptide complexes. ${ }^{12}{ }^{13}$ Thus HLA-DM molecules are involved in the antigen processing pathway of HLA class II restricted antigen presentation.

Both DMA and DMB genes show polymorphism in the third exon. ${ }^{14}{ }^{15}$ Three polymorphic sites have been found in DMA and two in DMB. According to the combinations of these polymorphisms, four different alleles at DMA- ${ }^{*} 0101$ to ${ }^{*} 0104$ - and five at $\mathrm{DMB}-{ }^{*} 0101$ to ${ }^{*} 0105$ - have been identified so far. ${ }^{14-16}$ The possibility arises that these polymorphisms could affect class II restricted antigen presenting pathway by altering their functions

Knowledge about possible involvement of DM molecules in the production of aPL would be helpful for a better understanding of the mechanisms of production not only of aPL but also of other autoantibodies. In an initial response to this question, we examined the susceptibility of the HLA-DM polymorphisms to aPL production.

\section{METHODS}

\section{Patients}

We recruited 51 patients with primary APS, 42 patients with APS secondary to systemic lupus erythematosus (SLE) (secondary APS), all fulfilling the Sapporo criteria for APS ${ }^{17}$ and the American College of Rheumatology criteria for SLE ${ }^{18}$, and 40 patients with SLE but without APS (none of whom had aPL). Their median age was 43 years (range 22 to 73 ), and the female to male ratio was 121:12. All the patients were seen in the Lupus Unit, St Thomas' Hospital, London and were involved in this study from 1995 to 1998 after giving informed consent. The control populations were represented by 109 blood donors at Guy's and St Thomas' Hospitals, London. All patients and controls were of white race, unrelated, and born in the United Kingdom.

\section{Genotyping of HLA-DM polymorphism}

Genomic DNA was extracted from peripheral white blood cells from the patients and the healthy controls using a standard phenol-chloroform extraction procedure or by salting out methods employing a kit (Nucleon BACC; Biosciences, Coatbridge, UK) according to the manufacturer's instructions. Samples of DNA were amplified for the third exon of DMA and DMB genes by polymerase chain reaction (PCR) using primers as previously described. ${ }^{19}$ PCR cycles consisted of an initial two minute denaturation at $95^{\circ} \mathrm{C}$ and 30 cycles of one minute denaturation at $95^{\circ} \mathrm{C}$, one minute annealing at $56^{\circ} \mathrm{C}$, and one minute extension at $72^{\circ} \mathrm{C}$. Amplified PCR products were then subjected to restriction fragment length polymorphism (RFLP) using Fok I, Hinf I, and Aci I endonucleases (New England Biolabs, Beverly,

Abbreviations: aPL, antiphospholipid antibodies; APS antiphospholipid syndrome; LA, lupus anticoagulant; RFLP, restriction fragment length polymorphism 
Table 1 The distribution of HLA-DM alleles in patients with antiphospholipid syndrome and controls

\begin{tabular}{|c|c|c|c|c|c|c|c|}
\hline Allele & $\begin{array}{l}\text { APS } \\
(n=186)\end{array}$ & & $\begin{array}{l}\text { PAPS } \\
(n=102)\end{array}$ & $\begin{array}{l}\text { SAPS } \\
(n=84)\end{array}$ & & $\begin{array}{l}\text { SLE APS } \\
(n=80)\end{array}$ & $\begin{array}{l}\text { Controls } \\
(n=218)\end{array}$ \\
\hline $\mathrm{DMA}^{*} 0101$ & $78.0 \%$ & & $79.4 \%$ & $76.2 \%$ & & $88.8 \%$ & $85.8 \%$ \\
\hline *0102 & $17.7 \S$ & & 14.7 & $21.4^{\top}$ & & 8.8 & 8.3 \\
\hline *0103 & 2.7 & $\dagger$ & 3.9 & 1.2 & $\ddagger$ & 2.5 & 3.2 \\
\hline *0104 & 1.6 & & 2.0 & 1.2 & & 0.0 & 2.8 \\
\hline $\mathrm{DMB}^{*} 0101$ & 75.8 & & 75.5 & 76.2 & & 75.0 & 69.7 \\
\hline *0102 & 1.1 & & 1.0 & 1.2 & & 3.8 & 2.3 \\
\hline *0103 & 22.0 & & 22.5 & 21.4 & & 21.3 & 25.7 \\
\hline *0104 & 1.1 & & 1.0 & 1.2 & & 0.0 & 2.3 \\
\hline *0105 & 0.0 & & 0.0 & 0.0 & & 0.0 & 0.0 \\
\hline
\end{tabular}

$\mathrm{n}=$ number of alleles in each group.

$\mathrm{tp}=0.035, \mathrm{tp}=0.011 v$ controls by $4 \times 2 \chi^{2}$ test.

$\S p=0.007(p c=0.028), \uparrow p=0.003(p c=0.012) v$ controls by $2 \times 2 \chi^{2}$ test.

APS, antiphospholipid syndrome; PAPS, primary antiphospholipid syndrome; SAPS, secondary antiphospholipid

syndrome; SLE, systemic lupus erythematosus.

Massachusetts, USA) for DMA alleles, and Hha I, Bsr I, and ApaL I (New England Biolabs) for DMB alleles. The enzymatic digestion was carried out over two hours at $65^{\circ} \mathrm{C}$ for Bsr I and at $37^{\circ} \mathrm{C}$ for the others. The digested samples were then subjected to electrophoresis in 3\% or, for Bsr I, $3.5 \%$ agarose gels and visualised with ethidium bromide. At least one sample was found positive for digestion in each PCR/digestion series, showing no failure in the PCR-RFLP process. DMA and DMB alleles were determined by combination of dimorphic sites according to the reports by Carrington et al, ${ }^{14}{ }^{15}$ and by Naruse et al for $\mathrm{DMB}^{*} 0105 .{ }^{16}$

\section{HLA-DRB 1 and DQB 1 typing}

In 234 individuals (127 patients and 107 controls), HLADRBl and DQBl had been genotyped by PCR with sequence specific primers (PCR-SSP). In each PCR reaction a primer pair was included that amplified human growth hormone (HGH I and II) and thus functioned as an internal positive amplification control. The primers, amplification protocol, and visualisation of the amplified products have been fully described. ${ }^{20} 21$

\section{Defection of aPL}

The presence of anticardiolipin antibody (aCL) was determined by enzyme linked immunosorbent assay (ELISA) according to the standardised technique. ${ }^{22}$

For the determination of anti- $\beta 2$-glycoprotein I antibody (aß2GPI), ELISA was carried out as previously described ${ }^{23} 24$ by using gamma irradiated plates (Maxisorp; Nunc, Roskilde,
Denmark), $50 \mu \mathrm{l}$ of $4 \mu \mathrm{g} / \mathrm{ml}$ purified human $\beta 2$-GPI (Yamasa Corporation, Choshi, Japan) in phosphate buffered saline (PBS) as an antigen, and 3\% porcine skin gelatin (Sigma, St Louis, Missouri, USA) as a blocking reagent.

Antiprothrombin antibody (aPT) was tested by ELISA using gamma irradiated plates (Maxisorp), $80 \mu \mathrm{l}$ of $10 \mu \mathrm{g} / \mathrm{ml}$ human purified prothrombin (Diagnostica Stago, Asneres, France) in PBS as an antigen, and $0.5 \%$ gelatin as a blocking reagent, as previously described..$^{25}$

The tests for lupus anticoagulant (LA) were carried out according to the guidelines of the Scientific and Standardization Subcommittee on $\mathrm{LA}^{26}$ using activated partial thromboplastin time and dilute Russell's viper venom time, diluted at $50 \%$ and corrected by plasma or platelets, respectively. Taipan snake venom time was used in the case of patients on warfarin. ${ }^{27}$

\section{Statistical analysis}

Comparisons of allelic frequencies of DM genes between different groups of patients and controls or between each DM and DR/DQ phenotype were undertaken using $\chi^{2}$ tests with Yates' correction when applicable. The probability $(\mathrm{p})$ values were further corrected by multiplying the number of comparisons $(\mathrm{pc})$ where needed; $\mathrm{p}$ (or $\mathrm{pc}$ ) $<0.05$ was regarded as statistically significant. For those two genes with the possibility of linkage disequilibrium, the delta $(\Delta)$ values-that is, the correlation coefficients in the $2 \times 2$ tables-were also calculated.

Table 2 The distribution of HLA-DM alleles and antiphospholipid antibodies

\begin{tabular}{|c|c|c|c|c|c|c|c|c|c|c|}
\hline \multirow[b]{2}{*}{ Allele } & \multicolumn{3}{|l|}{$\mathrm{aCl}$} & \multicolumn{2}{|l|}{ aß2GPI } & \multicolumn{2}{|l|}{ aPT } & \multirow[b]{2}{*}{$\begin{array}{l}\text { LA } \\
(n=124)\end{array}$} & & \multirow[b]{2}{*}{$\begin{array}{l}\text { Controls } \\
\text { ( } n=218\end{array}$} \\
\hline & $\begin{array}{l}\lg G \\
(n=134)\end{array}$ & & $\begin{array}{l}\lg M \\
(n=46)\end{array}$ & $\begin{array}{l}\lg G \\
(n=90)\end{array}$ & $\begin{array}{l}\lg M \\
(n=18)\end{array}$ & $\begin{array}{l}\lg G \\
(n=38)\end{array}$ & $\begin{array}{l}\lg M \\
(n=44)\end{array}$ & & & \\
\hline DMA *0101 & $76.1 \%$ & & $76.1 \%$ & $81.1 \%$ & $83.3 \%$ & $84.2 \%$ & $81.8 \%$ & $75.8 \%$ & & $85.8 \%$ \\
\hline *0102 & $20.1 \S$ & & 19.6 & 14.4 & 16.7 & 10.5 & 18.2 & 21.0 & + & 8.3 \\
\hline *0103 & 2.2 & $\uparrow$ & 2.2 & 2.2 & 0.0 & 5.3 & 0.0 & 1.6 & $\mp$ & 3.2 \\
\hline${ }^{*} 0104$ & 1.5 & & 2.2 & 2.2 & 0.0 & 0.0 & 0.0 & 1.6 & & 2.8 \\
\hline DMB *0101 & 75.4 & & 73.9 & 75.6 & 72.2 & 71.1 & 75.0 & 75.0 & & 69.7 \\
\hline *0102 & 1.5 & & 0.0 & 0.0 & 0.0 & 2.6 & 0.0 & 0.0 & & 2.3 \\
\hline *0103 & 23.4 & & 23.9 & 24.4 & 27.8 & 23.7 & 25.0 & 23.4 & & 25.7 \\
\hline *0104 & 0.7 & & 2.1 & 0.0 & 0.0 & 2.6 & 0.0 & 1.6 & & 2.3 \\
\hline *0105 & 0.0 & & 0.0 & 0.0 & 0.0 & 0.0 & 0.0 & 0.0 & & 0.0 \\
\hline
\end{tabular}

$\mathrm{n}=$ number of alleles in patients with positive antibodies $\mathrm{tp}=0.012, \pm \mathrm{p}=0.007 v$ controls by $4 \times 2 \chi^{2}$ test. $\S p=0.002(p c=0.008), \quad p=0.001(p c=0.004) v$ controls by $2 \times 2 \chi^{2}$ test. a $\beta 2$ GPI, anti- $\beta 2$ GPI antibody; $a C L$, anticardiolipin antibody; $a P T$, anti-prothrombin antibody; LA, lupus anticoagulant. 
Table 3 Frequencies of DMA alleles in patients with or without antiphospholipid antibodies (aPL) in SLE

\begin{tabular}{|c|c|c|c|c|c|}
\hline Allele & $\begin{array}{l}\mathrm{aPL}+/- \\
(\mathrm{n}=84 / 80)\end{array}$ & $\begin{array}{l}\mathrm{aCL}+/- \\
(\mathrm{n}=70 / 94)\end{array}$ & $\begin{array}{l}a \beta_{2} G P I+/- \\
(n=50 / 110)\end{array}$ & $\begin{array}{l}\text { aPT }+/- \\
(n=32 / 120)\end{array}$ & $\begin{array}{l}\mathrm{LA}+/- \\
(\mathrm{n}=58 / 90)\end{array}$ \\
\hline $\mathrm{DMA}^{*} \mathrm{O}$ & 7 & 7 & R & $5 \%$ & $6.7 \%$ \\
\hline${ }^{*} 0102$ & & 21 & & & 24 \\
\hline${ }^{*} 0103$ & $1.2 / 2.5$ & $1.4 / 2.1$ & $2.0 / 1.8$ & $0.0 / 2.5$ & $0.0 / 3.3$ \\
\hline${ }^{*} 0104$ & $1.2 / 0.0$ & $1.4 / 0.0$ & $0.0 / 0.9$ & $0.0 / 0.8$ & $0.0 / 1.1$ \\
\hline
\end{tabular}

$\mathrm{n}=$ number of alleles in patients with positive aPL $v$ patients with negative aPL among SLE patients. aCL, a $\beta_{2} \mathrm{GPI}$, and aPT contain both $\lg G$ and $\lg M$ class.

$\mathrm{tp}=0.035$ by $4 \times 2 \chi^{2}$ test.

$\neq \mathrm{p}=0.021(\mathrm{pc}=0.084)$ by $2 \times 2 \chi^{2}$ test.

a $32 \mathrm{GPI}$, anti- $\beta 2 \mathrm{GPI}$ antibody; $\mathrm{aCL}$, anticardiolipin antibody; $\mathrm{aPT}$, anti-prothrombin antibody; LA, lupus

anticoagulant.

\section{RESULTS \\ The distribution of HLA-DM alleles in patients and controls}

The allelic frequencies of DMA and DMB genes among controls were comparable with those previously reported on white populations, ${ }^{14}{ }^{15} 28$ indicating the successful genotyping of these genes (tables 1 and 2).

The distribution of DMA alleles was significantly different between APS patients or secondary APS patients and controls by $4 \times 2 \chi^{2}$ testing ( $\mathrm{p}=0.035$ and 0.011 , respectively). Among four DMA alleles, the increase in DMA*0102 showed the strongest contribution with these differences $(\mathrm{p}=0.007$ and $0.003, \mathrm{p} c=0.028$ and 0.012 , respectively, by $2 \times 2 \chi^{2}$ test). The distribution of DMA alleles in primary APS patients or SLE patients without APS was not significantly different from that in controls (table 1).

In the same manner, the significant difference of the distribution of DMA alleles was observed between patients with IgG aCL or with LA and controls $(p=0.012$ and 0.007, respectively), mainly reflecting the increase in $\mathrm{DMA}^{*} 0102$ in the former groups (table 2). The allelic frequency of DMA $^{*} 0102$ in patients with IgG aPT was close to that of controls (table 2).

\section{The distribution of HLA-DM alleles in patients with or without aPL among SLE patients}

Among the SLE patients, the skewing of the distribution of DMA alleles, including the increase in $\mathrm{DMA}^{*} 0102$, in patients with LA compared with those without LA was significant by $4 \times 2 \chi^{2}$ testing $(p=0.035)$ (table 3$)$. None of the DMB alleles was significantly different between patients with and without aPL among SLE patients (data not shown).

\section{Association with the known APS related HLA genes}

By the genotype analysis of 107 controls, the presence of $\mathrm{DMA}^{*} 0102$ was strongly associated with that of DRBI*0701 $(\mathrm{p}<0.0001, \Delta=0.470)$ and DQBI*0303 $(\mathrm{p}<0.0001, \Delta=$ $0.609)$, both of which were also closely associated with each other $(\mathrm{p}<0.0001, \Delta=0.451)$. They have been known to be positively associated with APS/aPL. The presence of DMA $^{*} 0102$ was not positively associated with that of other known APS related genes $\left(\mathrm{DQBI}^{*} 0301 / 4\right.$, $\mathrm{DQBI}^{*} 0302$, $\mathrm{DQBI}^{*} 0602 / 11$, and DRBI*1302). Among 127 APS and/or SLE patients, $\mathrm{p}$ values (and $\Delta$ values) for these associations were $0.002(\mathrm{p} c=0.17)(\Delta=0.302)$ for $\mathrm{DMA}^{*} 0102 v$ DRB1 ${ }^{*} 0701$ and $0.069(\Delta=0.190)$ for $\mathrm{DMA}^{*} 0102 v$ DQB1*0303. In the APS patient group, they were 0.003 $(\mathrm{p} c=0.25)(\Delta=0.343)$ and $0.59(\Delta=0.093)$, respectively. Furthermore, in this dataset the allelic frequency of $\mathrm{DRBI}^{*} 0701$ and DQBI${ }^{*} 0303$ was not significantly different between APS patients and controls (11.9\% $v 15.9 \%, \mathrm{p}>0.05$ and $7.4 \% \vee 5.1 \%, \mathrm{p}>0.05$, respectively).

\section{DISCUSSION}

The association between HLA class II genes and aPL production has been reported, ${ }^{3-10}$ not only showing that HLA class II or a linked gene is one of the genes leading to susceptibility to aPL production, but also suggesting that the $\mathrm{T}$ cell recognition of peptides bound to HLA class II molecules is required for generating aPL. Through these studies, the increased frequencies of HLA-DRB1*04, DRB1 ${ }^{*} 07$ (0701), DRB1*1302, DR53, DQB1*0301 (DQ7), *0302, and *0303 in APS patients have been shown.

In addition to these classical class II molecules, it has recently been revealed that HLA-DM molecules play crucial roles in HLA class II restricted antigen presentation, by studies of cell lines lacking HLA-DM, which are defective in class II restricted antigen processing. ${ }^{11-13}$ The presence of polymorphisms in DM genes ${ }^{14}{ }^{15}$ raised the possibility of their involvement in the development of HLA class II associated diseases, although the relation between these polymorphisms and the function of DM molecules has not yet been clarified. Several studies of the association between these HLA-DM polymorphisms and immunological diseases have been reported, including atopic dermatitis, ${ }^{19}$ insulin dependent diabetes, ${ }^{29}{ }^{30}$ sarcoidosis, ${ }^{31}$ multiple sclerosis, ${ }^{32}$ juvenile dermatomyositis, ${ }^{33}$ rheumatoid arthritis, ${ }^{34-38}$ and SLE. ${ }^{39}$ Some of these studies showed the presence of the association, such as the increased frequency of $\mathrm{DMA}^{*} 0103$ and $\mathrm{DMB}^{*} 0102$ in patients with juvenile dermatomyositis ${ }^{33}$ and the increased frequency of $\mathrm{DMA}^{*} 0103^{34}$ or $\mathrm{DMB}^{*} 0101^{38}$ in French patients with rheumatoid arthritis. The study on SLE, in a Japanese population, did not find any significant association of the HLA-DM polymorphisms with the development of SLE and specific manifestations, but the existence of aPL was not considered. ${ }^{39}$ We examined the susceptibility of these polymorphisms to aPL production in a white British population, and observed the skewed distribution of DMA alleles including the increase of $\mathrm{DMA}^{*} 0102$ in patients with aPL, which is the first report on HLA-DM and aPL/APS. The minor effect of the DMA polymorphisms on the presence of aPT, especially of IgG class, suggested the importance of another genetic predisposition in aPT production.

It is necessary to consider the influence of other genes in linkage disequilibrium with HLA-DM genes. Several associations between HLA-DM and classical class II genes in the white population are already known, including $\mathrm{DMA}^{*} 0102$ and DRB1 ${ }^{*} 07-\mathrm{DQAl}{ }^{*} 0201-\mathrm{DQB1}{ }^{*} 0303$ haplotype, $\mathrm{DMA}^{*} 0102$, and $\mathrm{DRBI}^{*} 01-\mathrm{DQAl}{ }^{*} 0101-\mathrm{DQB1}{ }^{*} 0501$ haplotype. ${ }^{28}$ Consistent with this, our study in a white British population showed association of $\mathrm{DMA}^{*} 0102$ with both $\mathrm{DRBI}^{*} 0701$ and $\mathrm{DQB1}{ }^{*} 0303$. Thus it is possible that the haplotype $\mathrm{DMA}^{*} 0102-\mathrm{DRB1}{ }^{*} 07-\mathrm{DQB}{ }^{*} 0303$ may be important in aPL production. In this study, we were not able to determine exactly which haplotype each individual had, as we did not investigate their families. However, in our series, 
neither DRB1*0701 nor DQB1*0303 was significantly associated with APS (the discrepancy from our previous report ${ }^{8}$ may reflect the partial difference of the population of the patients and controls). The weaker association between $\mathrm{DMA}^{*} 0102$ and $\mathrm{DRBI}^{*} 0701$ or $\mathrm{DQBI}^{*} 0303$ in APS patients than in controls was compatible with these results. They suggest that the DMA gene itself could be influential to the production of aPL.

More than half of aPL positive patients did not have $\mathrm{DMA}^{*} 0102$, indicating the implication of other genetic risk factors for aPL production separate from DMA*0102 or $\mathrm{DMA}^{*} 0102$ containing haplotype. Furthermore, the presence of a considerable number of individuals with DMA*0102 but without aPL suggests the requirement of a coexistence of other genetic or environmental (for example, infections) factors for aPL production.

\section{ACKNOWLEDGMENTS}

This work was supported by Lupus UK. We are grateful to Mrs Kiran Parmar for performing the tests for lupus anticoagulant.

\section{Authors' affiliations}

M L Sanchez, K Katsumata, T Atsumi, F I Romero, M L Bertolaccini,

A Funke, O Amengual, G R V Hughes, M A Khamashta, Lupus Research Unit, The Rayne Institute, St Thomas' Hospital, London SEI, UK

E Kondeatis, R W Vaughan, Tissue Typing Department, Guy's Hospital, London SE1, UK

A Cox, Institute for Cancer Studies, University of Sheffield Medical School, Sheffield, UK

\section{REFERENCES}

1 Demaison C, Ravirajan CT, Isenberg DA, Zouali M. Analysis of variable region genes encoding anti-Sm and anti-cardiolipin antibodies from a systemic lupus erythematosus patient. Immunology 1995:86:487-94.

2 Menon S, Rahman MAA, Ravirajan CT, Kandiah D, Longhurst CM, McNally T, et al. The production, binding characteristics and sequence analysis of four human $\lg G$ monoclonal antiphospholipid antibodies. J Autoimmunity 1997; 10:43-57.

3 Arnett FC, Olsen ML, Anderson KL, Reveille JD. Molecular Analysis of major histocompatibility complex alleles associated with the lupus anticoagulant. J Clin Invest 1991;87:1490-5.

4 Hartung K, Coldewey R, Corvetta A, Deicher H, Kalden JR, Krapf F, et al. $M H C$ gene products and anticardiolipin antibodies in systemic lupus erythematosus. Results of a multicenter study. Autoimmunity 1992;13:95-9.

5 Asherson RA, Doherty DG, Vergani D, Khamashta MA, Hughes GRV. Major histocompatibility complex associations with primary antiphospholipid syndrome. Arthritis Rheum 1992;35:124-5.

6 Wilson WA, Scopelitis E, Michalski JP, Pierangeli SS, Silveira LH, Elston RC, et al. Familial anticardiolipin antibodies and C4 deficiency genotypes that coexist with MHC DQB1 risk factors. J Rheumatol 1995;22:227-35.

7 Wilson WA. Histocompatibility genes in antiphospholipid antibody syndrome. Lupus 1996;5:259-62.

8 Caliz R, Atsumi T, Kondeatis E, Amengual O, Khamashta MA, Vaughan RW, et al. HLA class II gene polymorphisms in antiphospholipid syndrome: haplotype analysis in 83 caucasoid patients. Rheumatology 2001;40:31-6.

9 Arnett FC, Thiagarajan P, Ahn C, Reveille DR. Associations of anti- $\beta 2$ glycoprotein I autoantibodies with HLA class II alleles in three ethnic groups. Arthritis Rheum 1999;42:268-74.

10 Bertolaccini ML, Atsumi T, Caliz AR, Amengual O, Khamashta MA, Hughes GR, et al. Association of antiphosphatidylserine/prothrombin autoantibodies with HLA class II genes. Arthritis Rheum 2000;43:683-8.

11 Kelly AP, Monaco JJ, Cho S, Trowsdale J. A new HLA-class II-related locus, DM. Nature 1991;353:571-3.

12 Mellins E, Smith L, Arp B, Corner T, Celis E, Pious D. Defective processing and presentation of exogenous antigens in mutants with normal HLA class II genes. Nature 1990;343:71.
13 Vogt AB, Kropshofer H, Hammerling GJ. How HLA-DM affects the peptide repertoire bound to HLA-DR molecules. Hum Immunol 1997;54:170-9.

14 Carrington M, Yeager M, Mann D. Characterization of HLA-DMB polymorphism. Immunogenetics 1993;38:446-9.

15 Carrington M, Harding A. Sequence analysis of two novel HLA-DMA alleles. Immunogenetics 1994;40:165.

16 Naruse TK, Kawata H, Ishihara M, Ando A, Kagiya M, Nose Y, et al. Analysis on allelic variation of the HLA-DMB gene in Japanese by PCR-RFLP as well as direct DNA sequencing and identification of a new DMB allele, $D M B^{*} 0105$. Tissue Antigens 1996;47:530-7.

17 Wilson WA, Gharavi AE, Koike T, Lockshin MD, Branch DW, Piette JC, et al. International consensus statement on preliminary classification criteria for definite antiphospholipid syndrome: report of an international workshop. Arthritis Rheum 1999:42:1309-11.

18 Tan EM, Cohen AS, Fries JF, Masi AT, McShane DJ, Rothfield NF, et al. The 1982 revised criteria for the classification of systemic lupus erythematosus. Arthritis Rheum 1982;25:1271-7.

19 Kuwata S, Yanagisawa M, Nakagawa H, Saeki H, Etoh T, Miyamoto M, et al. HLA-DM gene polymorphisms in atopic dermatitis. J Allergy Clin Immunol 1996;98:S192-200.

20 Olerup O, Zetterquist H. HLA-DR typing by PCR amplification with sequencespecific primers (PCR-SSP) in 2 hours: an alternative to serological DR typing in clinical practice including donor-recipient matching in cadaveric transplantation. Tissue Antigen 1992;39:225-35.

21 Olerup O, Aldener A, Fogdell A. HLA-DQB1 and -DQA1 typing by PCR amplification with sequence-specific primers (PCR-SSP) in 2 hours. Tissue Antigen 1993:41:119-39.

22 Harris EN, Gharavi AE, Patel SP, Hughes GRV. Evaluation of the anticardiolipin antibody test: Report of an international workshop held 4 April 1986. Clin Exp Immunol 1987;68:215-22.

23 Matsuura E, Igarashi Y, Yasuda T, Triplett DA, Koike T. Anticardiolipin antibodies recognize 32 -glycoprotein I structure altered by interacting with oxygen modified solid phase surface. J Exp Med 1994;179:457-62.

24 Amengual O, Atsumi T, Khamashta MA, Koike T, Hughes GRV. Specificity of ELISA for antibody to $\beta 2$-glycoprotein I in patients with antiphospholipid syndrome. Br J Rheumatol 1996;35:1239-43.

25 Bertolaccini ML, Atsumi T, Khamashta MA, Amengual O, Hughes GRV. Autoantibodies to human prothrombin and clinical manifestations in 207 patients with systemic lupus erythematosus. J Rheumatol 1998;25:1 104-8.

26 Brandt JT, Triplett DA, Alving B, Scharer I. Criteria for the diagnosis of lupus anticoagulants: an update. Thromb Haemost 1995;74:1185-90.

27 Rooney AM, McNally T, Mackie IJ, Machin SJ. The Taipan snake venom time: a new test for lupus anticoagulant. J Clin Pathol 1994;47:497-501.

28 Diilali-Saiah I, Benini V, Daniel S, Assan R, Bach JF, Caillat-Zucman S. Linkage disequilibrium between HLA class II (DR,DQ,DP) and antigen processing (LMP, TAP, DM) genes of the major histocompatibility complex. Tissue Antigens 1996:48:87-92.

29 Djilali-Saiah I, Benini V, Schmitz J, Timsit J, Assan R, Boitard C, et al. Absence of primary association between DM gene polymorphisms and insulindependent diabetes mellitus or celiac disease. Hum Immunol 1996;49:22-7.

30 Esposito L, Lampasona V, Bonifacio E, Bosi E, Ferrari M. Lack of association of DMB polymorphism with insulin-dependent diabetes. J Autoimmunity 1997; 10:395-400

31 Ishihara M, Naruse T, Ohno S, Kawata H, Mizuki N, Yamagata N, et al. Analysis of HLA-DM polymorphisms in sarcoidosis. Hum Immunol 1996;49:144-6.

32 Ristory G, Carcassi C, Lai S, Fiori P, Cacciani A, Floris L, et al. HLA-DM polymorphisms do not associate with multiple sclerosis: an association study with analysis of myelin basic protein T cell specificity. J Neuroimmunol 1997:77:181-4.

33 West JE, Reed AM. Analysis of HLA-DM polymorphism in juvenile dermatomyositis (JDM) patients. Hum Immunol 1999;60:255-8.

34 Pinet V, Combe B, Avinens O, Caillat-Zacman S, Sany J, Clot J, et al. Polymorphism of the HLA DMA and DMB genes in rheumatoid arthritis. Arthritis Rheum 1997:40:854-8.

35 Yen JH, Chen CJ, Tsai WC, Tsai JJ, Chang JG, Liu HW. HLA-DMA and DMB genotyping in patients with rheumatoid arthritis. J Rheumatol 1992;24:442-4.

36 Takeuchi F, Nabeta H, Kuwata S, Tanimoto K, Ito K. Association of DMA and DMB with RA in Japanese. Clin Exp Rheumatol 1997;15:189-92.

37 Singal DP, Ye M. HLA-DM Polymorphisms in patients with rheumatoid arthritis. J Rheumatol 1998;25:1295-8.

38 Perdriger A, Guggenbuhi P, Chaled G, Yaouanq J, Quelvennec E, Bonnard MN, et al. Positive association of the HLA DMB1*0101-0101 genotype with rheumatoid arthritis. Rheumatology 1999;38:448-52.

39 Takeuchi F, Nabeta H, Hong GH, Kuwata S, Tanimoto K, Ito K. Polymorphisms of DMA and DMB genes in Japanese systemic lupus erythematosus. Br J Rheumatol 1998;37:95-7. 